\title{
Re-energizing Japan's teikei movement: Understanding intergenerational transitions of diverse economies
}

Special issue:

Food as a Tool for Social Change FALK

\author{
Chika Kondo * \\ Kyoto University
}

Submitted January 4, 2021 / Revised February 19, March 20, and April 26, 2021 /

Accepted April 27, 2021 / Published online September 16, 2021

Citation: Kondo, C. (2021). Re-energizing Japan's teikei movement: Understanding intergenerational transitions of diverse economies. Journal of Agriculture, Food Systems, and Community Development, 10(4), 103-121. https://doi.org/10.5304/jafscd.2021.104.0031

Copyright (C) 2021 by the Author. Published by the Lyson Center for Civic Agriculture and Food Systems. Open access under CC-BY license.

\begin{abstract}
In the 1960s-70s, Japan's teikei movement, also referred to as Japanese community supported agriculture (CSA), emerged as a response to a period marred with multiple food scandals and environmental injustices and resulted in direct partnerships between consumers and organic farmers. Although this movement peaked in the 1990s just as the concept of alternative food networks (AFNs) gained popularity in western countries, little is known about what has happened to teikei today. This paper analyzes how teikei exemplifies diverse economies and explores how the possibilities of noncapitalist economic practice currently exist compared to the founding movement principles. Through case studies of two
\end{abstract}

* Chika Kondo, Department of Natural Resource Economics, Graduate School of Agriculture, Kyoto University; Kitashirakawa Oiwake-cho; Sakyo Ward, Kyoto 606-8502 Japan; +81-070-4283-7928; chika.kondo.84r@st.kyoto-u.ac.jp teikei groups in the Kansai region of Japan that transitioned their leadership to younger generations, I assess how changes made by current generations allow teikei to adapt to challenges that have long plagued the movement, such as the decline of volunteer labor provided by housewives. Drawing on a diverse economies approach, I argue that, despite current members' detachment from strong activist identities, they sustain their organizations through part-time work, community building, and institutionalizing volunteer labor. The successes and struggles of current teikei groups provide insight into how AFNs seeking to build alternative economies can overcome difficulties that emerge from actualizing diverse economies.

\section{Keywords}

Diverse Economy, Teikei, Alternative Food Network, Organic Agriculture, Everyday Activism, Direct-to-Consumer, Community Supported Agriculture, CSA 


\section{Introduction}

The concept of alternative food networks (AFN) emerged in the 1990s largely in opposition to global, industrialized conventional food supply chains (Renting et al., 2003). However, Japan's sansho-teikei (teikeel) ${ }^{1}$ movement holds a slightly different history: it was formed in the 1960s-70s in response to consumers concerned with food scares and environmental harm resulting from the heavy use of agrichemicals and producers who opposed the industrialization of agriculture. In addition, several prominent doctors also began advocating the importance of diets without agrichemicals based on their research which drew connections between illness and diet (Honjoh, 2004). The teikei movement, often referred to as Japan's alternative food movement (Kondoh, 2015) or the Japanese version of CSA (Hatano, 2008), is defined as the co-partnership between consumers and producers operating their own direct distribution system. According to the founders of the Japan Organic Agriculture Association ${ }^{2}$ (JOAA), the teikei movement served as the vehicle for social transformation where both producers and consumers actively engaged in building an alternative food system centered on organic agriculture. In addition, teikei prioritizes mutual understanding and developing trust between producers and consumers, exemplifying the major tenets of AFNs such as economic viability for producers, ecologically sound growing practices, and social equity (Feenstra, 1997; JOAA, 2004; Kondoh, 2015). However, as AFNs gained popularity in the 1990 s, the teikei movement witnessed a decline due to changing social structures such as the aging of leaders and farmers, loss of volunteer labor from housewives as more women entered the workforce, and expansion of commer- cialized organic produce sold in mainstream supermarkets.

This paper does not seek to assess the decline of teikei as a movement. Rather, it focuses on how current formations of teikei overcome the struggles that the overall movement has faced. Within AFN literature, there have been criticisms regarding the nature of AFN as an over-glorification of smallscale agriculture and its creation of exclusive niche markets accessible only to affluent consumers (Allen \& Sachs, 1991; Guthman, 2008; Tregear, 2011). This has prompted an interrogation on what constitutes the 'alterity' of AFNs, leading scholars to dabble in diverse economies and/or noncapitalist spaces ${ }^{3}$ (Gritzas \& Kavoulakos, 2016; Rosol, 2020; Wilson, 2013). Diverse economies describe the economic practices that exist outside of what feminist geographers Gibson and Graham refer to as capitalocentrism (Gibson-Graham \& Dombroski, 2020). Capitalocentrism refers to the set of economic practices and relationships in which capitalism is the "dominant, most efficient, modern, innovative, and dynamic form] of economic activity that ha[s] hitherto existed" (Gibson-Graham \& Dombroski, 2020, p. 8). Indeed, AFNs such as teikei were developed to oppose this form of economic practice. teikei, with its several variations in how direct partnerships were formed, exemplify diverse economies where nonmarket transactions, such as workshare and bartering, and nonmarket benefits, such as trust and mutual aid, occur. Inspired by Gibson-Graham's diverse economies scholarship, this paper investigates how teikei groups that have transitioned their leadership beyond the founding generation overcome barriers that arise in implementing diverse economies and/or noncapitalist economic practice. Barriers include issues arising

\footnotetext{
${ }^{1}$ Teikei in Japanese means "partnership." In English publications sansho-Teikei and sanchoku-Teikei are often confused. Sanchoku-Teikei refers to a partnership developed by consumer cooperatives that were looking to source directly from a producer or group of producers and did not specifically adhere to the same principles of sansho-Teikei and the organic agriculture movement. For purposes of this paper, I will refer to teikei to represent sansho-Teikei as represented by the organic agriculture movement.

2 JOAA is the national organization of organic farmers in Japan that was formed at the start of the organic agriculture movement. It holds annual conferences and regularly publish magazines and books that promote its activities. It operates as an independent body but serves as an umbrella organization for many Teikei groups.

${ }^{3}$ Noncapitalist refers to Gibson-Graham's critique of the universal nature of capitalism which dominates discussion on capital flows only operating in a capitalist manner. They argue that there are other, alternative, or 'noncapitalist' economic practices that exist, although they often remain invisible (Gibson-Graham, 2008). Such economic practices that remain outside the dominant capitalist structure constitute what is known as the diverse economy.
} 
from dependence on volunteer labor, difficulties in supporting viable farmer livelihoods, and declines in political activism.

The paper is organized as follows. First, I contextualize the diverse economies approach with AFN literature and show how the teikei principles align with this approach. Second, I present the two case studies of teikei groups that have undergone intergenerational transitions and have adopted orientations that differ from their founding ones. Third, I show how their transitions have overcome the challenges that emerge from the actualization of noncapitalist economic practices. I demonstrate how participation in the everyday activities of farming, processing orders, and communicating with members have served as opportunities for reflection about contemporary connections to food and agriculture, thereby highlighting teikei as a different diverse economy. Lastly, this paper defines the potentials and limitations that emerge in developing today's alternative food systems, as AFN practitioners often face messy contradictions of imagining alternatives to life under capitalism.

\section{Background}

\section{Diverse Economies: A Relative Lens on Alterity} The concept of alternative food networks (AFNs) encapsulates the many initiatives organized by individuals who manage food distribution models outside of the conventional food system. Many such initiatives were originally set up to challenge monolithic worldviews and create alternative reconfigurations of capitalist society (Goodman et al., 2013). However, the literature on AFNs over the last two decades has generated many useful critiques to help understand what has suppressed the capacity for AFNs to transform a food system where "ethical food" moves beyond simply being an "alternative" to conventional food (Blumberg et al., 2020; Bruce \& Som Castellano, 2017; Cameron \& Wright, 2014; Goodman et al., 2013; Goodman \& DuPuis, 2002; Guthman, 2008; Sarmiento, 2017; Wilson, 2012). For example, Watts, Ilbery, and Maye (2005) discuss how some farmers who participate in AFNs must also distribute to conventional food systems to achieve economic viability. Guthman (2008) describes how AFNs reinforce neoliberal subjectivities where individual consumer choice and entrepreneurialism are heralded in the face of deregulation and emphasis on free market and free trade ideology. Thus, in questioning the impact of AFNs and their ability to create social change, the debate on the alterity of AFNs has introduced the exploration of AFNs that encompass noncapitalist economic practices. Examples of AFNs that operate as noncapitalist economic practice includes CSAs that utilize work exchange, cooperatively owned farms, and food collectives, where transactions exist outside of the conventional flows of capital but can come in other forms such as bartering or collective ownership (Koretskaya \& Feola, 2020; Rosol, 2020; Sarmiento, 2017; Wilson, 2013).

Not all AFNs inhere noncapitalist economic practices. However, the influential work of feminist economic geographers Katherine Gibson and Julie Graham and their introduction of diverse economies provides a relative lens to understand AFNs as "ongoing experiments in ethical economic relations scattered across a landscape that is already economically heterogenous" (Sarmiento, 2017, p. 486). Because AFNs are often interpreted as a universal term encompassing the wide variety of food systems that operate outside the mainstream (Tregear, 2011), the diverse economies lens provides a more intentional attempt to position AFNs outside conventional, monolithic corporate capitalism. For diverse economy scholars, diversity exists within markets, property, labor practices, social relations, and transactions (Gibson-Graham, 2006; Gritzas \& Kavolukaos, 2016; Healy et al., 2020). Therefore, AFNs, which entail noncapitalist economic practices such as teikei, provide a useful understanding of what and how such alternatives exist within this heterogeneous landscape.

However, in analyzing the transformative potential of diverse economies, it is also important to engage with the contradictions and challenges that often emerge between intentions and practices (e.g., 'self-exploitation' of farmers practicing CSA [Galt, 2013] and underlying power imbalances between actors [Suryanata et al., 2020]). For example, Suryanata et al. (2020) point out how new farmers in Hawaii enter with a strong commitment to social values but often face a weak financial outlook due 
to their reliance on unpaid labor and grants, and, therefore, end up quitting after a few years. Other critiques of the diverse economies approach point to its abstract nature and the risk of celebrating noncapitalist practices that may also be exploitative (Samers, 2005).

The diverse economies approach assesses how noncapitalist economic practices are both envisioned and put into practice. This generates the opportunity to explore and navigate the various challenges that emerge in building and imagining an alternative while still living under capitalism. Chatterton and Pickerill (2010), in their seminal work on 'everyday activism,' point to the messy space of activism and everyday life that are intertwined in the work to create alternative, postcapitalist imaginaries (Gibson-Graham, 2006). Indeed, according to Wilson (2012) and Gritzas and Kavoulakos (2015), the current rise of noncapitalist economic practices such as CSA can pose as sites for postcapitalist deviations from the mainstream. This collective academic work implies that practitioners, such as the evolving membership in teikei groups, also face the same challenges in "imagining and enacting a new economic politics" (Wilson, 2012, p. 11), in which the ideals of noncapitalist practices must be continuously realigned with the everyday reality of meeting people's needs.

\section{Teikei's Diverse Economies Approach}

Beginning in 1971, teikei served as the praxis of Japan's organic movement, where the relationships between producers and consumers were not based on business transactions but rather on friendship, equality, and mutual support. It began with the rejection of organic food being bought and sold as a commodity and aimed to reconfigure social relationships, even if it was viewed as economically inefficient. At the peak of this movement in the 1990s, there were approximately $250-832^{4}$ teikei groups (Hatano, 2008; JOAA, 2004). Consumers, mostly urban housewives, organized themselves into collective groups that reached out to producers who later self-organized into producer groups. There are various formations and styles of teikei groups, such as (1) farmer groups partnering with consumer groups, (2) individual farmers connecting to a group of consumers, and (3) individual farmer to individual consumer relations (Hatano, 1998). More traditional forms of teikei and the case studies featured in this study resemble the first type. The third type, individual farmer to individual consumers, is typically associated with the western CSA model and is utilized by many new entry farmers in Japan today. The premise of teikei rests on being a direct distribution system based on trust generated from personal relationships between producers and consumers (Akitsu \& Aminaka, 2010). This partnership is maintained because both parties actively provide resources such as labor and capital and coordinate the infrastructure and logistics needed to carry out distribution. Thus, not only does teikei operate outside of the conventional food system, but by having both consumers and producers share the labor and resources necessary to carry out their alternative distribution system, they are indeed practicing diverse economies.

In 1978, the JOAA established the 10 principles of the teikei movement, which were used as a foundational blueprint to define how the relationships between producers and consumers existed as a form of noncapitalist economic practice. These principles outline how teikei represents a form of a diverse economy. Figure 1 provides the list of 10 principles of teikei as translated by JOAA. The first principle highlights how the relationship between producer and consumer rejects being explicitly transactional and emphasizes how mutuality is necessary. This is further elaborated in the $4^{\text {th }}$ and $5^{\text {th }}$ principles, which discuss the negotiation of prices and distribution of labor. It was commonly agreed upon that it was much more difficult to produce food than it was to consume food, therefore requiring ongoing mutual understanding. Some teikei groups put this into practice via a variety of ways such as fixed price setting, full acceptance of a producers' harvest, and/or holding regular meetings to discuss and negotiate prices. Other groups also practiced bartering or gift economies (Orito, 2014), where gifts or services

\footnotetext{
${ }^{4}$ According to the JOAA, there has never been a comprehensive official survey on teikei groups. Therefore, it is difficult to know exactly how many teikei groups were in existence.
} 
were exchanged instead of money. However, the most effective practice in strengthening the relationship between producers and consumers was through “援農” ennō (literal definition: en = support and $n \bar{o}=$ agriculture), where consumers go and physically help with farm labor. This type of volunteer farm labor engagement served as not only an educational space but also a space to share perspectives and build mutual understanding behind farming and household cooking and consumption.

According to the above principles, teikei served as a vehicle for the movement by ensuring that farmers and consumers planned the growing schedule together (Principle 2) and that consumers accepted the entire harvest no matter the severity of pest or crop damage (Principle 3). Distribution logistics were not to be outsourced to third parties but rather facilitated by either producer or consumer groups (Principle 6). Democratic management and ongoing study groups and education ensured active engagement from all members (Principle 7 and 8). The last principles address the balance between moving towards ideal

\section{Figure 1. Ten Principles of Teikei}

1. Principle of mutual assistance. The essence of this partnership lies, not in trading itself, but in the friendly relationship between people. Therefore, both producers and consumers should help each other on the basis of mutual understanding: This relation should be established through the reflection of past experiences.

2. Principle of intended production. Producers should, through consultation with consumers, intend to produce the maximum amount and maximum variety of produce within the capacity of the farms.

3. Principle of accepting the produce. Consumers should accept all the produce that has been grown according to previous consultation between both groups, and their diet should depend as much as possible on this produce.

4. Principle of mutual concession in the price decision. In deciding the price of the produce, producers should take full account of savings in labor and cost, due to grading and packaging processes being curtailed, as well as of all their produce being accepted; and consumers should take into full account the benefit of getting fresh, safe, and tasty foods.

5. Principle of deepening friendly relationships. The continuous development of this partnership requires the deepening of friendly relationships between producers and consumers. This will be achieved only through maximizing contact between the partners.

6. Principle of self-distribution. On this principle, the transportation of produce should be carried out by either the producer's or consumer's groups, up to the latter's depots, without dependence on professional transporters.

7. Principle of democratic management. Both groups should avoid over-reliance upon limited number of leaders in their activities, and try to practice democratic management with responsibility shared by all. The particular conditions of the members' families should be taken into consideration on the principle of mutual assistance.

8. Principle of learning among each group. Both groups of producers and consumers should attach much importance to studying among themselves, and should try to keep their activities from ending only in the distribution of safe foods.

9. Principle of maintaining the appropriate group scale. The full practice of the matters written in the above articles will be difficult if the membership or the territory of these groups becomes too large. That is the reason why both of them should be kept to an appropriate size. The development of this movement in terms of membership should be promoted through increasing the number of groups and the collaboration among them.

10. Principle of steady development. In most cases, neither producers nor consumers will be able to enjoy such good conditions as mentioned above from the very beginning. Therefore, it is necessary for both of them to choose promising partners, even if their present situation is unsatisfactory, and to go ahead with the effort to advance in mutual cooperation.

Source: Japan Organic Agriculture Association (JOAA, 2004) (already translated into English). 
alternatives and meeting the needs of the current reality as an ongoing challenge to overcome (Principles 9 and 10). This prompted a strong unspoken understanding where engagement in teikei was driven by a commitment to the movement and the progression of the group's shared common goal of social transformation.

At the start of the movement, the media frenzy concerning food safety (e.g., the Morinaga Milk arsenic poisoning incident in 1955) and the news of environmental pollution scandals (e.g., the Minamata disease outbreak from methylmercury poisoning 1956 and Yokkaichi asthma from sulfur dioxide emissions in the 1960s) urgently prompted many housewives to find trustworthy sources for safe food. They looked to teikei groups as a solution (Honjoh, 2004). However, as these food crises faded away from the public eye and organic agriculture products were slowly introduced to various natural food stores and small groceries by the 1980s, consumers began to lose the incentive to participate in teikei groups as more options became available (Harayama, 2011). The 1990s pointed to a large decline in teikei, often explained as the result of women increasingly entering the workforce (Kondoh, 2015). Kondoh (2015) points out how children of teikei members were not interested in joining teikei as they started their own families, with many finding it unrealistic to commit to teikei's practices. As housewives' capacity to volunteer declined, Hatano (2008) argues that teikei groups had difficulty building financial viability to pay for staff to coordinate producers and consumers. The decline of teikei points to major challenges that emerge with noncapitalist economic practices, including unsustainability stemming from reliance on volunteer labor and the subsequent impact in supporting producer livelihoods. This calls into question how teikei groups today function, given that Japan holds one of the highest rates of women in the workforce. Yet women continue to bear the biggest burden for household food purchasing and preparation.

\section{Methods}

This paper focuses on two case studies that are based outside of the North American and European context. Additionally, these case studies focus on AFNs that formed as noncapitalist economic practices with a strong movement orientation and later transitioned their leadership towards a younger generation. I analyze the motives and shifts in awareness of those who participate in teikei groups today, particularly those in paid positions. Both groups are within the Kansai region of Japan in Osaka and Mie Prefectures (see Figure 2). I conducted data collection (e.g., participant observation of meetings and delivery routes and text analysis of annual reports, weekly newsletters, and meeting records), and carried out interviews between

\section{Figure 2. Map of Case Study Sites (Hirakata in Osaka Prefecture and Iga} Yūki in Mie Prefecture)

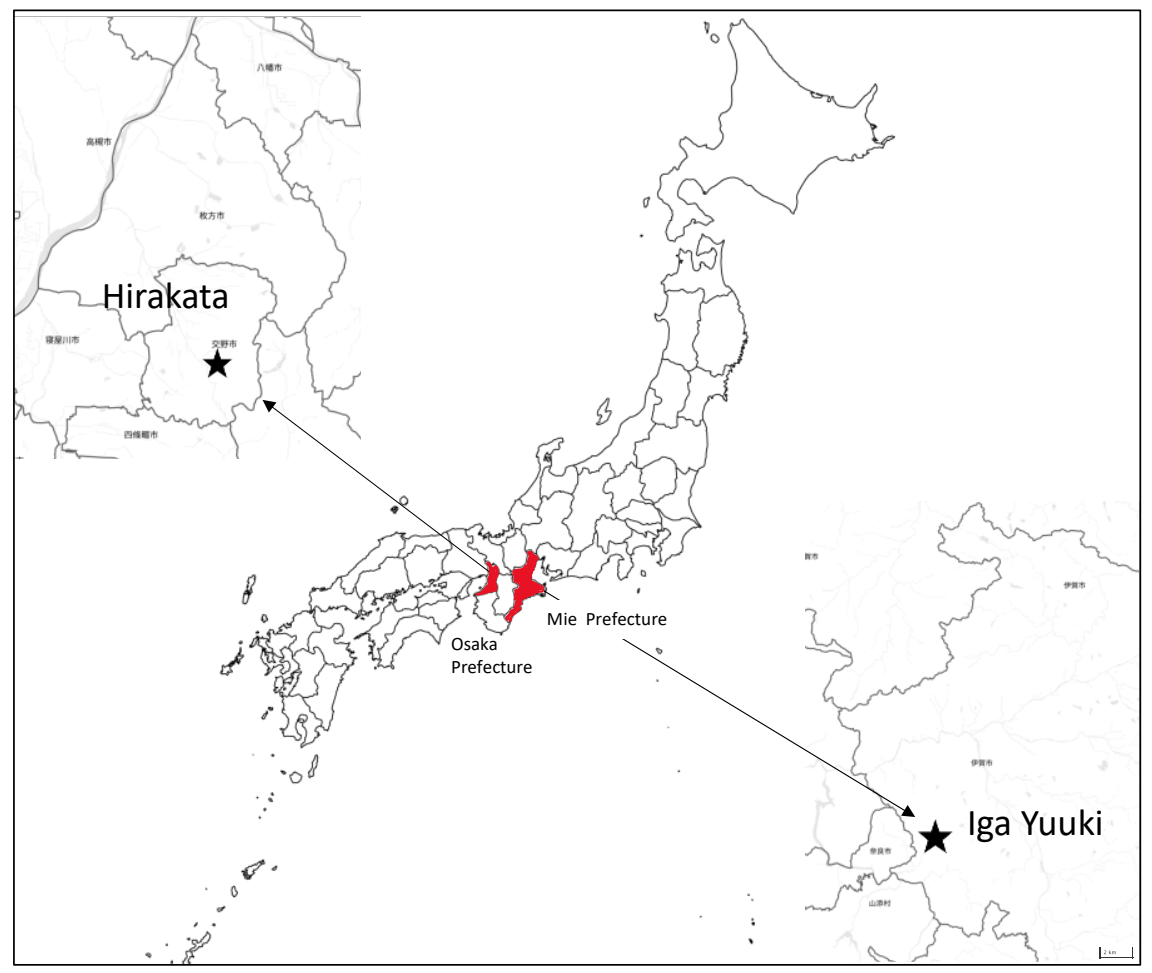


November 2019 and October 2020. These case studies were selected based on their ability to transition their leadership and engage new members since the decline of Teikei in the 1990s. The case studies represent two styles of Teikei, one that is consumer-led (Hirakata) and one that is producerled (Iga Yūki). I was introduced to many Teikei groups when I was volunteering at a conference hosted by the JOAA in 2018, where I met one of the founders of the Hirakata group. Our conversations led to my participation in other related events where I met an elder based in Mie Prefecture who then introduced me to the Iga Yüki group. Questions asked of members concerning their entry and motive to participate, what they gained from their involvement, and how they view their relationship to their respective organizations provided understanding about their engagement with Teikei as a diverse economy. Under the diverse economies approach, human subjectivity and its process of 'becoming' provide insight into what postcapitalist politics are desired to look like (Gibson-Graham, 2006; Healy et al., 2020). The findings of this paper are based on semi-structured interviews with 20 consumer-part-time workers, three consumer members, seven farmers, and multiple rounds of informal interviews with informant memberleaders both of the founding generation and current leadership in each respective group. During my research, I faced some obstacles related to COVID-19, which impacted the frequency and size of gatherings since April 2020, when Japan went into its first emergency lockdown. Because I was not a member of either group, I had some difficulty in observing staff meetings as some members were immunocompromised, and the gathering size was limited. However, I was fortunate to participate in some event gatherings, follow distribution routes, conduct farm visits, and volunteer on farms. Since the pandemic began, all interviews were conducted outside and followed social distancing protocols, including mask-wearing and limiting travel on public transportation. For instance, I often used my bike to reach farm sites. In addition, follow-up discussions were done over the phone or through social media platforms during the state of emergency periods when mobility was limited.

\section{Findings and Analysis}

While many teikei groups struggled without the support of volunteer labor from housewives in post-bubble Japan, other teikei groups adapted to changing social environments by implementing services such as individual delivery, limiting the quantity of produce in the weekly box, and relaxing its emphasis on teikei as a social movement (Yamamoto, 2020). Each section below details the evolution of teikei from its original form to its more contemporary form. Based on a relative perspective of the diverse economies approach, I analyze how the shifts made to address the challenges of maintaining noncapitalist practices illustrate an evolution of the 'who' and their desires associated with carrying out a postcapitalist transformation.

\section{From Political Education to Professionalized Solidarity'}

Hirakata Shokubin Kōgai to Kenkō wo Kangaeru Kai (Hirakata Thinking about Food Contamination and Health) (Hirakata) is a consumer-led teikei group that began in 1975 as a study group of 72 housewives who wanted to understand the issues behind food contamination outbreaks and connections between agrochemicals, food safety, and health. Led by a group of seven housewives, they reached out to peri-urban farmers in surrounding areas who were new entry farmers who had quit their careers in the 1970s. These farmers were the most willing to adapt to agrichemical-free growing styles. This group carried out teikei principles as the farmers organized and carried out the following tasks: harvest drop-off, processing (assisting volunteers with redistribution into weekly vegetable boxes), delivery of the boxes via three distribution routes carried out three days a week, and weekly contributions to the newsletter attached to each box. Hirakata leaders and volunteers assemble the montly newsletter, hold monthly meetings discussing distribution, planting schedules, and price setting, and are responsible for budgeting, accounting, and processing payments. Both producers and consumers contribute their thoughts on food, agriculture, and everyday life to the weekly and monthly newsletter. 
However, as the group reached its peak in 1980 (see Table 1), they faced several struggles in maintaining financial viability and had to downsize their operations by moving to smaller offices and processing facilities. While moving offices and undergoing various leadership transitions, some of the membership data were lost (which explains the gap in Table 1 from 1980 to 1997).

By the late 1990s, the decline in membership instigated concerns over supporting the livelihood of their producer members. One farmer wrote in their monthly newsletter and weekly message:
It's not worth it to call it a job, it's not worth it to call it a hobby, it's a way of life. I'm not growing it for you and you aren't just buying it from me. I'm not doing organic farming as a favor, I'm doing it out of my own beliefs. As farmers all over Japan are collapsing, nothing is more encouraging to me than to continue organic farming in the midst of the collapse of Japan.

His message provided an enduring sense of hope as members struggled to recalibrate and

\section{Table 1. Hirakata Chronology}

\begin{tabular}{|c|c|c|}
\hline Date & $\begin{array}{l}\text { Member } \\
\text { Count }\end{array}$ & Activities \\
\hline 1975 & 72 & $\begin{array}{l}\text { Held study group for mothers and housewives who were gravely concerned about health, food } \\
\text { safety, the future of their children, school food, medical treatments, and environmental degradation. } \\
\text { Provided childcare support which encouraged more mothers to participate. }\end{array}$ \\
\hline 1976 & 400 & $\begin{array}{l}\text { Started their collective buying club and organized an organic farming group, and later joined JOAA. } \\
\text { Within a year of their establishment, they had over } 400 \text { members with } 40 \text { han; each han held a } \\
\text { leader who met monthly to build out their alternative food system effectively. Participating members } \\
\text { voted on leadership. }\end{array}$ \\
\hline 1977 & & $\begin{array}{l}\text { Established an office and hired } 3 \text { people for distribution and secured } 2 \text { administrative positions } \\
\text { working twice a week. }\end{array}$ \\
\hline 1978 & 450 & $\begin{array}{l}\text { Many women volunteers participated in the processing of vegetable boxes. They created } 10+ \\
\text { administrative positions and } 30+\text { who volunteered in carrying out delivery and logistics. } 50 \text { han } \\
\text { units. }\end{array}$ \\
\hline 1980 & 500 & $\begin{array}{l}\text { Peak membership: continually published writings on how eating is tied to the way of life and raising } \\
\text { life. They published a recipe book and printed over } 28,000 \text { copies. }\end{array}$ \\
\hline 1997 & - & $\begin{array}{l}\text { Decided to stop full acceptance of harvest and, through consensus decision making, decided to } \\
\text { raise the prices of vegetables by } 5 \% \text { and lower the proportion of sales going back to the producer } \\
\text { from } 80 \% \text { to } 75 \% \text {. }\end{array}$ \\
\hline 2005 & $248(123)^{\mathrm{a}}$ & $\begin{array}{l}\text { Membership falls to half of the peak size. The big issues they faced were that they didn't have } \\
\text { enough members to support the livelihood of farmers. They started a monthly newsletter as the } \\
\text { number of members continuously declined. They started doing more recreational projects such as } \\
\text { calligraphy, arts and crafts, mahjong, harmonica, hiking, etc. }\end{array}$ \\
\hline 2008 & $230(115)$ & $\begin{array}{l}\text { Generational shift in the elected president, as someone in their } 40 \text { s replaces those of the founding } \\
\text { generation (who were in their } 70 \text { s at the time). }\end{array}$ \\
\hline 2017 & $\begin{array}{l}145 \\
(76)\end{array}$ & $\begin{array}{l}\text { They move offices to a farm shed of one of the farmers into an administrative office that they share } \\
\text { with the local botanical garden support association and begin discussions with a local alternative } \\
\text { pre-school. }\end{array}$ \\
\hline 2019 & $161(83)$ & $\begin{array}{l}\text { Leadership and staff transition from } 70 \text { s to } 40 \text { s. } \\
15 \text { new members join who are mostly mothers from nearby forest pre-school. }\end{array}$ \\
\hline
\end{tabular}

Source: compiled and summarized based on organizations annual reports and interviews with founding members* number who receive teikei box $\dagger$

* There is a gap in data between 1981 and 2004 as membership data was lost in the transition of offices as they downsized to accommodate for the decline in members.

$\dagger$ To accommodate the decline in members who no longer were able or did not want to receive a weekly box, the organization allowed for different membership types. In addition, not all members who received boxes were receiving them weekly, as some opted for biweekly. 
achieve financial sustainability to continue their operations.

The early 2000s were particularly troublesome as they struggled to find connection and significance in carrying out the organization as a social movement. 2005 was the first turning point for intergenerational leadership transition. The new leader had made it clear that she, being from a different generation, held a different belief system, one that veered away from strong notions of activism:

I'm doing it because I want to. When you say movement, it drains me. ... What connects people and things is not 'logic' but through people talking to people on an equal level.

The 2010s were difficult as the organization discussed closing its operations on numerous occasions. However, 2018 and 2019 brought a breath of fresh air as the transition and downsizing of offices provided a new opportunity for connection. Hirakata moved into a producer member's farm shed that was renovated into a shared space for the nearby botanical garden and alternative forestry pre-school and nursery (which needed a sheltered space for rainy days). Meeting the other tenants of the farm shed engendered at least 15 mothers of the alternative preschool to become members of Hirakata's teikei. The influx of members also catalyzed a full transition of the entire administrative staff to a generation of women (mostly in their 30s and 40s) who were not of the founding generation (now in their 70s and 80s). All the administrative staff are paid part-time workers in this transition, although their hourly wage sits below the prefectural minimum wage. Concerning the transition, one of the founding members expressed that,

I don't expect the younger staff to do what we did. I know that it is often difficult to follow in someone else's footsteps, but we really are just so happy to see someone younger than us take interest. Perhaps they won't fully engage in organic agriculture movement the way we did, but there are interesting things happening in (Katano) about uplifting the community and supporting local.

While on the brink of collapse, the almost serendipitous connection with the local alternative preschool not only provided a means to transition the group's leadership but also continue its legacy of solidarity through a more professionalized form.

\section{From Abandoned Land to New Farmers}

The next case study I introduce is Iga Yükinousanbutsu-kyōkyü-center (Iga Yūki), which was established as a producer-led organization with three farms in 1984 (see the detailed chronology in Table 2). The founding leader began his farming career working on a farm directly owned and operated by another longstanding teikei group in Kyoto. He participated in the student protest movement of the 1960s, ${ }^{5}$ which influenced his formation of Iga Yūki, symbolizing organic agriculture as the physical manifestation of the former peace movement. The group currently operates as a nonprofit organization of 17 farmers. Iga Yūki is located in Iga City in the Mie Prefecture; the city holds a unique association with organic agriculture. It hosts Japan's only organic agriculture high school and a commune associated with the Yamagishi movement. ${ }^{6}$ Iga Yūki can attribute its success to the high availability of abandoned land left fallow since World War II (approximately 500 hectares), which allowed Iga Yūki to provide new and beginning farmers with land and the chance to establish their farming career as they developed various types of AFN models to collectively distribute their produce. Each farmer runs their own

\footnotetext{
${ }^{5}$ During the 1960s, Japan faced its greatest mass political demonstrations protesting the U.S.-Japan Mutual Security Treaty, referred to as Anpo (Movement). This movement featured a large mobilization of student activists across several universities in Japan (Krauss, 1988)

${ }^{6}$ The Yamagishi movement started in the 1980s and established intentional communities where residents live with minimal possessions and do not conduct monetary transactions within the community. They mostly run poultry raising and egg production operations.
} 
Table 2. Iga Yūki Chronology

\begin{tabular}{|c|c|c|}
\hline Date & $\begin{array}{l}\text { Farmer } \\
\text { Count }\end{array}$ & Activities \\
\hline 1981 & & $\begin{array}{l}\text { The founder of this organization trained under one of the founders of natural farming, Tarobei Kumon, who } \\
\text { moved to Iga City (as there was } 500 \text { ha of abandoned fully irrigatable farmland that was developed after } \\
\text { WWII) and started a training center. This served as the foundation for what would later become lga Yūki. }\end{array}$ \\
\hline 1984 & 3 & $\begin{array}{l}\text { They started as three farmers who aimed to use food as a way to disconnect from Japan's bubble economy } \\
\text { mindset focused on the pursuit of efficiency and convenience. Before the spread of chisan-chisho }{ }^{1} \text { they } \\
\text { were already focused on local production for local distribution. Their growing style centers on a } \\
\text { regenerative approach without greenhouses and added agriculture chemicals or synthetic fertilizer. }\end{array}$ \\
\hline 1988 & & $\begin{array}{l}\text { They became involved with the anti-nuclear movement after seeing the aftermath of Chernobyl. They } \\
\text { began connecting with nearby fishermen and held classes on handling chicken and fish. }\end{array}$ \\
\hline 1989 & & $\begin{array}{l}\text { They began supplying rice in addition to vegetables. They started hosting study groups and experiences for } \\
\text { consumers and producers to plant rice, weed, and harvest together. }\end{array}$ \\
\hline 1992 & 4 & $\begin{array}{l}\text { They changed their growing style from many (50-100) varieties to a medium (20-30) diversity of varieties } \\
\text { to accommodate the expansion of consumer cooperatives in multiple prefectures. }\end{array}$ \\
\hline 1995 & & Started vending as a direct farm stand in the neighboring city, Nabari City. \\
\hline 2004 & 9 & $\begin{array}{l}\text { Leadership changes to another family and thus begins a system of taking in apprentices and nurturing } \\
\text { farm successors in Iga; their apprenticeship program becomes fully established in } 2010 \text {, where } \\
\text { apprentices enter a 2-year program with the goal of becoming an independent farmer in their } 3^{\text {rd }} \text { year. }\end{array}$ \\
\hline 2008 & 11 & $\begin{array}{l}\text { The direct sales shop, Yüki Genkiya, opens in Nabari with the help of their consumers. Consumers and } \\
\text { producers developed the business together. }\end{array}$ \\
\hline 2011 & 14 & $\begin{array}{l}\text { Two farmers who joined in } 2009 \text { began Norasuke, an opportunity for consumers and nearby residents to } \\
\text { work part-time on the farm. Their teikei-style distribution also faced significant growth from } 40 \text { to } 300 \\
\text { households. }\end{array}$ \\
\hline 2012 & 18 & $\begin{array}{l}\text { They re-establish themselves as a nonprofit organization rather than just a distribution group for farmers. } \\
\text { The organization connects consumers and producers to live out their values of } 1 \text {. Living with nature and all } \\
\text { living things. } 2 \text {. Taking our own lives into our own hands and be closely tied to the land that feeds us } 3 \text {. } \\
\text { Doing it yourself. }\end{array}$ \\
\hline 2019 & 14 & $\begin{array}{l}\text { The goals of the organization shift priorities towards trying to better stabilize the livelihood of farmers, } \\
\text { expand farmland cultivation, accept new trainees, and build deeper connections with consumers to } \\
\text { expand their reach. }\end{array}$ \\
\hline
\end{tabular}

† Chisan-chisho, or "local production for local consumption," refers to a policy initiative developed by the Ministry of Agriculture, Fisheries, and Forestry (MAFF) to improve food self-sufficiency and boost domestic production via a new branding scheme to restore trust in the safety of food (Nishiyama \& Kimura, 2005).

operation but collectively grows between 50 and 60 varieties, with any one farmer growing between 10 and 30 varieties. Planting schedules are negotiated among the farmers and decided by the needs of their various market outlets. Before 2011, they primarily distributed their produce to Kyoto and the surrounding Kansai region. They delivered to both teikei groups and consumer cooperatives and operated a weekly direct farm stand in the neighboring city every Tuesday morning, where any leftover crops were sold at reduced prices.

In 2010, three new and beginning farmers joined the group; their participation helped expand the teikei-style distribution system from $40 \mathrm{mem}$ - bers in 2010 to 300 members by 2012. They currently have 370 members. Every Friday, two producers personally distribute the boxes within the surrounding area. There are two types of boxes: Type A includes seven varieties sold at 1080 yen (US\$10) (delivery fee is included), and Type B features seven to 10 varieties sold at 1200-1400 yen (US\$13.50). Each box comes with a newsletter with the listed varieties, producers' names, and a reflection written by one of the member farmers.

Since the founding of their organization, they practice the principle of ennō by hosting monthly events inviting consumers and consumer groups to come to the farm and participate in community- 
building activities. In 2011, at one of these farm events, one of the newer farmer members pitched an idea to another consumer member to develop a part-time work opportunity on their farm. The initiative is called Norasuke, where anyone is welcome to come to the farm, work part-time in the field, and assist with processing and packaging. Norasuke was set up with intentional flexibility so that mothers could come freely on the days that worked best for their schedules and bring their children to the farm to play while they worked. The motivation behind the program was to give consumers a better understanding of how food is grown on the farm. For the farmer, the economic inefficiencies in hosting inexperienced people as farmhands outweighed the nonmarket impacts, allowing for the teikei principle of ennō to occur.

\section{From Volunteerism to Institutionalization...} Gibson-Graham (2006) emphasizes the interdependence of economic subjects as a critical component of diverse economies where interdependence is not fixated on realizing a specific ideal but rather is a more versatile exploration of "economic being-in-common" (p. 86). The changes made by teikei groups also reflect the shifts in mindsets of younger members and their diversity of perspectives. Table 3 provides an overview of the parttime workers interviewed who worked at Hirakata or Norasuke. The semi-structured interviews better clarified their motivation for involvement and provided hints as to why participants diverged from activist identities, which served as a strong foundation and basis for teikei as a social movement.

Despite the variety in motives for participation, there was little to no mention of a desire to hold an activist identity or engage in a hard label of "movement" building. Some came because they heard there was an opportunity for employment that had flexibility. As a young mother or as a retired woman, they found it was the appropriate amount of work that could be managed and still get home in time to cook dinner and carry out other household responsibilities. One of the founding organizers of Norasuke mentioned:

It is not common practice or, actually, one is not in a position to ask someone to volunteer.
Volunteering is something that one chooses out of their own fruition. When I was approached to see if there would be any mothers in the area interested in working on the farm, I was taken aback at first. But at the time, I had a two-month-old daughter and was concerned about how I would ever be able to go back into the workforce, and so we began this interesting project. Before you know it, it's been 10 years.

Another interviewee from Hirakata said,

I used to see the sign for their organization: Hirakata Thinking about Food Contamination and Health Association, and I honestly believed it was some kind of a cult. It seemed very intimidating. ... However, once another mother from the same forest pre-school that my child attends was telling me about purchasing a weekly vegetable box grown locally, I was eager to buy. I had no idea it was the same organization.

The difficulties in recruiting volunteers and cult-like impressions made teikei groups unapproachable and developed a wall of exclusivity. There were participants in both groups who carried a distaste for 'movements,' which contrasted with the founding members. Many founding members shared anecdotes about hosting political education workshops and engaging in weekly study on connections between organic agriculture and environmental sustainability or other social issues such as the dominance of nuclear power plants. The spirit and discipline of the movement were a clear source of motivation for those of the founding generation.

Very few of the new members carried explicit motivations related to teikei principles or the desire to critically engage in the decommodification of food. For instance, not all those who worked for Hirakata or Norasuke were exclusively teikei consumers. In fact, the consumption patterns varied from some mothers who said they went to the supermarket every day in addition to their weekly box to those who said they could only afford to buy organic vegetables from teikei and weren't sure if they would be able to afford it when their children grew older and consumed more food. The 
Table 3. Profiles of Interviewees

\begin{tabular}{|c|c|c|c|c|c|c|}
\hline No. & Age & Org. & Years & Motivation to join & How they found out about it & Consumption pattern \\
\hline 1 & $40 s$ & Hirakata & 2 & Health & Through a friend & Receives only vegetable box \\
\hline 2 & $40 s$ & Hirakata & 2 & Children have allergies & From pre-school & Receives only vegetable box \\
\hline 3 & $40 s$ & Hirakata & 2 & Looking for part-time work & From pre-school & Buys from teikei and supermarket \\
\hline 4 & $80 s$ & $\begin{array}{l}\text { Hirakata } \\
\text { (consumer) }\end{array}$ & - & Widowed & From neighbor & $\begin{array}{l}\text { Buys from teikei and consumer } \\
\text { cooperative }\end{array}$ \\
\hline 5 & $40 \mathrm{~s}$ & $\begin{array}{l}\text { Hirakata } \\
\text { (consumer) }\end{array}$ & - & $\begin{array}{l}\text { Used to work for an organic } \\
\text { business }\end{array}$ & From friend & Buys from teikei \\
\hline 6 & $40 s$ & Hirakata & 2 & Looking for flexible work & $\begin{array}{l}\text { Recommendation from } \\
\text { nursery school }\end{array}$ & Receives only vegetable box \\
\hline 7 & $40 \mathrm{~s}$ & Hirakata & 20 & Health & From a friend & Buys from teikei \\
\hline 8 & $30 \mathrm{~s}$ & Hirakata & 5 & Looking for part-time work & $\begin{array}{l}\text { Father is one of the } \\
\text { farmers }\end{array}$ & Vegetables from farm and teikei \\
\hline 9 & $50 s$ & Hirakata & 25 & $\begin{array}{l}\text { Was involved in organizing } \\
\text { around environmental } \\
\text { pollution }\end{array}$ & Attended a lecture & $\begin{array}{l}\text { Buys from teikei and supplements } \\
\text { with consumer cooperative }\end{array}$ \\
\hline 10 & $50 s$ & Hirakata & 20 & Grew up with lots of allergies & Through a friend & $\begin{array}{l}\text { Buys from teikei and supplements } \\
\text { with natural food stores }\end{array}$ \\
\hline 11 & $40 s$ & Hirakata & 3 & $\begin{array}{l}\text { Concerned about eating } \\
\text { ethically }\end{array}$ & From pre-school & $\begin{array}{l}\text { Buys from teikei and natural food } \\
\text { companies }\end{array}$ \\
\hline 12 & $70 \mathrm{~s}$ & Hirakata & 30 & $\begin{array}{l}\text { Didn't know anything about } \\
\text { cooking and living in urban } \\
\text { area }\end{array}$ & $\begin{array}{l}\text { Learned about it from } \\
\text { tea ceremony class }\end{array}$ & $\begin{array}{l}\text { Currently living alone, widowed. Mainly } \\
\text { consumes from teikei }\end{array}$ \\
\hline 13 & $70 \mathrm{~s}$ & Hirakata & 45 & Concerned with food safety & Founder & Buys from teikei \\
\hline 14 & $70 \mathrm{~s}$ & Hirakata & 45 & & Founder & Buys from teikei \\
\hline 15 & $30 \mathrm{~s}$ & Iga Yūki & 1 & Children have allergies & $\begin{array}{l}\text { Buys from Iga Yūki farm } \\
\text { stand }\end{array}$ & Pretty strictly organic \\
\hline 16 & $70 \mathrm{~s}$ & Iga Yūki & 4 & $\begin{array}{l}\text { Moved recently and needed } \\
\text { to find something to do }\end{array}$ & $\begin{array}{l}\text { Her daughter receives } \\
\text { weekly box }\end{array}$ & $\begin{array}{l}\text { Used to never purchase vegetables, } \\
\text { but now enjoys cooking with } \\
\text { vegetables }\end{array}$ \\
\hline 17 & $50 s$ & Iga Yūki & 6 & $\begin{array}{l}\text { Had an organization about } \\
\text { children and connecting } \\
\text { them to food }\end{array}$ & $\begin{array}{l}\text { Farmer reached out to } \\
\text { her to start Norasuke }\end{array}$ & $\begin{array}{l}\text { teikei and occasional trips to favorite } \\
\text { organic stores. }\end{array}$ \\
\hline 18 & $40 s$ & Iga Yūki & 4 & $\begin{array}{l}\text { Had two small children that } \\
\text { loved to play outside }\end{array}$ & Friends with Farmer & Buys from teikei \\
\hline 19 & $30 \mathrm{~s}$ & Iga Yūki & 2 & $\begin{array}{l}\text { Wanted to meet more } \\
\text { people }\end{array}$ & $\begin{array}{l}\text { Neighbor receives } \\
\text { weekly box }\end{array}$ & $\begin{array}{l}\text { Shops every day at the supermarket } \\
\text { plus teikei }\end{array}$ \\
\hline 20 & $50 s$ & Iga Yūki & 8 & $\begin{array}{l}\text { Holds own business; comes } \\
\text { once a week }\end{array}$ & Through an event & $\begin{array}{l}\text { Shops at local corner and buys } \\
\text { domestic at grocery store }\end{array}$ \\
\hline 21 & $70 \mathrm{~s}$ & Iga Yūki & 5 & Likes gardening & Heard from friend & $\begin{array}{l}\text { Doesn't buy from Iga Yūki but buys } \\
\text { from direct market }\end{array}$ \\
\hline 22 & $50 s$ & Iga Yūki & 7 & $\begin{array}{l}\text { Flexibility of schedule for } \\
\text { part-time work }\end{array}$ & $\begin{array}{l}\text { Lives walking distance } \\
\text { from farm }\end{array}$ & Eats seasonally; buys teikei \\
\hline
\end{tabular}

strict adherence to consuming exclusively through teikei proved difficult both on economic and philosophical levels. One interviewee noted, "This idea of movement. It just seems very hard. Especially today when there is so much information out there. I don't know what to believe anymore." The above examples point out the difficulties involved in achieving the principles of the teikei, as it presents as an almost fixed fantasy that cannot be met by younger generations who face other hurdles unveiled by other aspects of subjectivity, such as class and educational background. 
The challenge remains in upholding the relevancy of the teikei movement and its principles. In contrast to the founding members who saw teikei as a vehicle for political and social transformation, current members do not hold a strong desire to address issues related to food and agriculture. Rather, they pointed to other social problems such as social isolation and social fragmentation. For example, many of the new members of Hirakata are connected through the alternative preschool and also regularly gather and participate in community events and grassroots operated programming that supports children in finding and believing in their inner-most self. Such group activities are invested in creating spaces that will provide their children a liberated space to be 'themselves.' These various events reflect a sense of wanting to instill in their children pride for themselves and the community they live in. There is not a strong notion of 'doing it because it's for the movement' or a sense of being in solidarity with other like-minded 'movements.' However, there is an underlying rejection of the mainstream and a desire to live an alternative life, which is also well documented in several accounts of new entry organic farmers in Japan who reject the rigidity of Japanese society (Hisano et al., 2018; McGreevey \& Akitsu, 2016; McGreevey, 2012; Rosenberger, 2017). For members of the current generation, engagement in teikei has more to do with supporting their local community over the act of transforming the food system. The younger generation and their values have reshaped the interdependence of economic subjects in diverse economies. Teikei has shifted from striving to achieve a certain ideal towards becoming a looser community, of which teikei serves as an element in the pursuit of living a meaningful life for group members and their children.

\section{From Decommodification to Viable Modern Livelihoods}

As the two cases present examples of the shifting teikei labor distribution (volunteer to paid) and the changing practice of enno, there remain several issues that both consumers and producers face. Teikei as a practice is rooted in the decommodification of food. However, it also faces the struggle of meeting both the needs of its producers and consumers. Both cases only provide part-time labor (vs. full-time labor) for consumers. While neither group depends on outside grants to operate their organizations, they actively strive to achieve financial sustainability. For instance, Norasuke is financially feasible because Iga Yūki growers create enough revenue to pay for their consumers to work on the farm. Iga Yūki growers hold multiple markets outside of their teikei model to distribute their produce. Their teikei system makes up approximately $40 \%$ of its distribution, and $50 \%$ goes towards other buyers, such as consumer cooperatives and a teikei group in Kyoto, which doesn't have weekly face-to-face interaction with consumers. The remaining $10 \%$ is sold through their direct sales market. Like many other CSAs that struggle to provide adequate economic wellbeing to the farmer (Pretty et al., 2010; White, 2020), producers in teikei must find additional markets to sustain their livelihood. Diversified distribution streams allow Iga Yūki to continue training additional farmers who will sustain a viable livelihood. Their collective scale as a group of farmers gives them autonomy to achieve parity pricing and ensures that they can sustain their local teikei system by offering their vegetable box at accessible prices and providing part-time work opportunities through Norasuke. One farmer stated,

I am a farmer in order to grow food for as many people that can eat what I grow. However, it is difficult to attract new farmers as they tend to want to grow the most lucrative crops. We all have our preferences in what we want to grow and what we have the skillset to grow. There is also the desire to not become a factory-style farm and yet be a farm that can still make enough to support our families as full-time commercial farmers.

Based on the two case studies, teikei is not a singular model that farmers can solely rely on to maintain their livelihood. In Hirakata, two of the four farmers are in retirement and receive pensions. The other half distribute to markets such as online sales or carry out their own individual-toindividual CSA style box scheme. The diversity of 
markets that farmers must engage in to maintain their livelihood is a larger reflection of the increasing number of choices consumers have today in accessing organically grown produce. This also reflects the diminishing influence of teikei and its function as an alternative economic practice. The teikei model alone cannot meet the needs of producers who must create viable livelihoods for themselves. Therefore, producers rely on other more capitalist economic exchanges and market transactions with larger-scale markets, such as consumer cooperatives and grocery stores, where the interaction with their consumers is not as intimate or robust as with their teikei consumers.

\section{Limited Accessibility of Teikei for Busy Lifestyles}

There are other limitations towards the type of people teikei can engage. This study did not collect class backgrounds of consumer-members. Additionally, this study cannot empirically back claims that systemic inequality and structural impediments limit who can engage in diverse economy-oriented AFNs where more time and sense of engagement outside of the market transaction is required (Alkon \& Guthman, 2017; Galt et al., 2019, Galt et al., 2017). However, within both case studies, there were little to no participants who were single-person households. Many respondents had mentioned that they don't see how single-person households would want to join based on their own experience living alone. Multiple people mentioned how before starting a family, they ate out constantly and never made time to cook for themselves as they were too busy to think about preparing their food the way they do so today. At the World Economic Forum in 2019, former Prime Minister Shinzo Abe had declared that $67 \%$ of women ages $15-64$ were working. However, Japan's continued decline in the World Economic Forum's Global Gender Gap Index (ranked 120 out of 156 countries in 2021) suggests that Japan's cultural norms still uphold a strong gendered division of labor in which women are expected to be responsible for most domestic labor including cooking and household chores. Therefore, teikei as a place for a parttime job and as a place where children are welcomed might provide greater appeal as an ideal situation given the little changes in gender roles and responsibilities at large.

\section{Discussion: Is Teikei still a diverse economy?}

\section{Re-imagining of Work and the Workplace}

While the use of paid labor and the loss of ennō/ volunteer labor might blur the lines of teikei operating as a diverse economy, I argue that there is a re-imagining of 'work' and 'workplace' that is taking place within both organizations. Reflections point towards additional forms of non-monetary exchange occurring:

I came here because I needed a job. I needed to find a job while my child was in nursery school. I felt like I had lost a sense of who I was since I became absorbed in child rearing. I like working here-I get to hear so many interesting stories about farmers and cooking skills I would have never thought about. (consumer member with Hirakata)

Both spaces were child-friendly, and I regularly witnessed children playing in the office and on the farm fields as their mothers worked on fulfilling orders, processing, and other farm activities. This kind of re-imagination of the workplace not only functions as a direct challenge to the monoculture of capitalocentrism but also presents a different imaginary, one where "transformation relies on reimagination as political labor" (Cooper et al., 2019 , p. 21). Furthermore, the use of paid labor does not signify the embodiment of 'neoliberal subjectivities' where individual behavior and choice serve as steadfast solutions to the ills of the conventional food system (Harris, 2009). While the exchange of money for labor represents a market exchange, the associated social relations and benefits that spur from interpersonal ties exhibit greater complexity (Hermann, 1997). In fact, AFNs like teikei might not have to be solely reactive or oppositional against capitalism but can be a subset of broader configurations of political and economic relations (Smith \& Jehlička, 2013). Based on my conversations with both groups, there were moments shared in which a strong sense of cama- 
raderie was recognized, where many members appreciated the openness of frank opinions being exchanged concerning food, cooking, caretaking, childrearing, and farming, and the occasional gossip and political news being shared and expressed. One of the members at Norasuke shared:

I cannot think of another workplace that would allow me and my friends to bring our children on the farm, and while they enjoy the outdoors, we are able to work and converse and take home leftover harvest that would otherwise go to compost.

Ennō as paid labor provides more sustainable access for people, especially mothers, to engage in teikei, which continues to manifest alternative possibilities to engage with a more intimate and local food system.

\section{Teikei as Space for Self-Transformation}

The interactions consumers shared on the farm, with farmers, and operating teikei created many opportunities for learning-by-doing and selftransformation. Not only are the lines between producer and consumer blurred in these spaces, but the conversations shared among farmers, consumers, and workers can catalyze findings of the self beyond their role of mother, wife, or retired woman. Some of the members of Norasuke took the core principles of teikei even further by starting their own garden plot at the farm fields:

I started a garden plot next to one of the fields where I'm planting edamame and herbs. I never thought I would be someone who could grow food. Of course, I'll never be a farmer, but I never realized how much I enjoy being able to work outside and be surrounded by nature. I even have gotten my husband to come and work on the weekends too.

The actions that have organically spurred from part-time work are representative of the collective action Gibson-Graham (2006) refers to in their proposition of the community economy as an "acknowledged space of social interdependency and self-formation" (p. 166). This everyday practice is built-in within a collective environment where economic possibilities beyond capitalism can occur-creating spaces of community within the workplace and deepening ties between people within a food supply chain. Orito (2014) also cites the transition away from movement orientation towards relationships that resemble family — such as when she describes the concept of morotomo ${ }^{7}$ in her case study of CSA in Japan.

Chatterton and Pickerill's (2010) analysis of everyday activism helps inform how daily practices such as engaging in teikei as paid work can forge new identities that embrace the obstacles that emerge in the in-between space of capitalist society and noncapitalist. Rather than resting on a clear distinction of activist and non-activist/capitalist and noncapitalist, the blurry space that experiments with making a "material difference to livelihoods" (Chatterton \& Pickerill, 2010, p. 487) aligns with the diverse economy approach. The transition of leadership from the founding generation to a younger generation provided opportunities for new ideas that were better suited for the shifts in values that diverge from strong activist orientation.

\section{Conclusion}

In this paper, I examine the practices of teikei groups that have transitioned their membership from the founding generation to a younger generation of members who currently raise children. The case studies of teikei provided in this paper offer insights into how organizations that held strong roots and ideals (i.e., noncapitalist economic practices) in establishing AFNs adapt to the changing realities, cultural values, and norms that occur within and across different generations. First, most current participants who work for teikei organizations in the two case studies reject identities associated with movement activism, representing a widening gap between the intentions of the founding leaders of teikei and the associated organic agriculture movement. Second, the transition of

\footnotetext{
${ }^{7}$ Morotomo refers to a notion of togetherness in the sense that one will be there for one another no matter what the circumstances are. It goes beyond the sense of co-existence as both parties take on the risk together.
} 
volunteer labor to paid labor and engagement in diversified distribution streams provides an opportunity for the essence of teikei movement principles to exist. Third, while the initial motivation of current members had little to do with teikei principles, the everyday practice and intimate engagement with alternative food systems provide a unique space for reflection for other noncapitalist imaginaries and new subjectivities to form. I argue that teikei today continues to embrace elements of diverse economies because the use of paid labor allows for members to continue to explore their interdependence and establish an economic beingin-common (Gibson-Graham, 2006). These findings show that despite the shifts in who carries out postcapitalist transformation, the outlook of the current teikei members and leaders confirm Gibson-Graham's (2006) reflection on how interdependence on economic subjects is not about being of the same but rather embracing difference. teikei still constitutes a diverse economy despite its loss of activist orientation because nonmarket benefits of self-transformation and the re-imagining of work are taking place within spaces where teikei activity occurs.

There are looming questions surrounding who will continue farming and whether weekly vegetable boxes will endure as future generations in Japan face increasing rates of aging, depopulation, and prepared food production and consumption (e.g., the average age of farmers currently is 70 years old, with only $10 \%$ of farmers under the age of 40 [McGreevey et al., 2019; Rigg et al., 2016]). Further research should look into how AFNs that embody diverse economies approaches address the challenges that occur in the blurred zone between living within the monoculture of centrocapitalism and establishing sustainable noncapitalist economic practices that meet the needs of both consumers and producers. Additional research should also analyze the class dynamics occurring among farmers and consumers, assessing whether or not teikei models in Japan are limited to more affluent consumers. AFN models such as teikei continue to face challenges in closing the gap between ideal alternative futures and reality. Digital agri-technologies are rapidly changing consumer habits, particularly how people engage with one another and their food. Trial and error of different methods to bring producers and consumers together in more meaningful ways outside of strictly market transactions will continue to inform the pathways for local equitable food systems to sustain themselves.

\section{Acknowledgments}

I would like to acknowledge the pioneers-both producers and consumers — of Japan's organic movement for building the infrastructure for experimentation and for striving for solidarity between grower and eater.

\section{References}

Akitsu, M., \& Aminaka, N. (2010, September). The development of farmer-consumer direct relationships in Japan: Focusing on the trade of organic produce. 4th Asian Rural Sociology Association (ARSA) International Conference, Legazpi City, Philippines.

Alkon, A. H., \& Guthman, J. (Eds.). (2017). The new food activism: Opposition, cooperation, and collective action. University of California Press. https://doi.org/10.1525/california/9780520292130.001.0001

Allen, P. (2010). Realizing justice in local food systems. Cambridge Journal of Regions, Economy and Society, 3(2), $295-308$. https://doi.org/10.1093/cjres/rsq015

Allen, P. L., \& Sachs, C. E. (1991). The social side of sustainability: Class, gender and race. Science as Culture, 2(4), 569-590. https://doi.org/10.1080/09505439109526328

Blumberg, R., Leitner, H., \& Cadieux, K. V. (2020). For food space: Theorizing alternative food networks beyond alterity. Journal of Political Ecology, 27(1), 1-22. https://doi.org/10.2458/v27i1.23026

Bruce, A. B., \& Som Castellano, R. L. (2017). Labor and alternative food networks: Challenges for farmers and consumers. Renewable Agriculture and Food Systems, 32(5), 403-416. https://doi.org/10.1017/S174217051600034X

Cameron, J., \& Wright, S. (2014). Researching diverse food initiatives: From backyard and community gardens to international markets. Local Environment, 19(1), 1-9. https://doi.org/10.1080/13549839.2013.835096 
Chatterton, P., \& Pickerill, J. (2010). Everyday activism and transitions towards post-capitalist worlds. Transactions of the Institute of British Geographers, 35(4), 475-490. https://doi.org/10.1111/j.1475-5661.2010.00396.x

Cooper, D., Dhawan, N., \& Newman, J. (Eds.) (2019). Reimagining the state: Theoretical challenges and transformative possibilities. Routledge. https://www.taylorfrancis.com/books/9781351209113

Coulson, H., \& Milbourne, P. (2020). Food justice for all?: Searching for the 'justice multiple' in UK food movements. Agriculture and Human Values, 38, 43-58. https://doi.org/10.1007/s10460-020-10142-5

DuPuis, E. M., \& Goodman, D. (2005). Should we go "home" to eat?: Toward a reflexive politics of localism. Journal of Rural Studies, 21(3), 359-371. https://doi.org/10.1016/j.jrurstud.2005.05.011

Feenstra, G. W. (1997). Local food systems and sustainable communities. American Journal of Alternative Agriculture, 12(1), 28-36. https://doi.org/10.1017/S0889189300007165

Galt, R. E. (2013). The moral economy is a double-edged sword: Explaining farmers' earnings and self-exploitation in community-supported agriculture. Economic Geography, 89(4), 341-365. https://doi.org/10.1111/ecge.12015

Galt, R. E., Bradley, K., Christensen, L., Fake, C., Munden-Dixon, K., Simpson, N., Surls, R., \& Van Soelen Kim, J. (2017). What difference does income make for community supported agriculture (CSA) members in California? Comparing lower-income and higher-income households. Agriculture and Human Values, 34(2), 435-452. https://doi.org/10.1007/s10460-016-9724-1

Galt, R. E., Bradley, K., Christensen, L. O., \& Munden-Dixon, K. (2019). The (un)making of “CSA people”: Member retention and the customization paradox in community supported agriculture (CSA) in California. Journal of Rural Studies, 65, 172-185. https://doi.org/10.1016/i.jrurstud.2018.10.006

Gibson-Graham, J. K. (2006). A postcapitalist politics. University of Minnesota Press.

Gibson-Graham, J. K. (2008). Diverse economies: Performative practices for 'other worlds.' Progress in Human Geography, 32(5), 613-632. https://doi.org/10.1177/0309132508090821

Gibson-Graham, J. K., \& Dombroski, K. (2020). The handbook of diverse economies. Edward Elgar Publishing. https://doi.org/10.4337/9781788119962

Goodman, D., \& DuPuis, E. M. (2002). Knowing food and growing food: Beyond the production-consumption debate in the sociology of agriculture. Sociologia Ruralis, 42(1), 5-22. https://doi.org/10.1111/1467-9523.00199

Goodman, D., DuPuis, M. E., \& Goodman, M. K. (2013). Alternative food networks: Knowledge, practice, and politics. Routledge. https://doi.org/10.4324/9780203804520

Gritzas, G., \& Kavoulakos, K. I. (2016). Diverse economies and alternative spaces: An overview of approaches and practices. European Urban and Regional Studies, 23(4), 917-934. https://doi.org/10.1177/0969776415573778

Guthman, J. (2008). Neoliberalism and the making of food politics in California. Geoforum, 39(3), 1171-1183. https://doi.org/10.1016/j.geoforum.2006.09.002

Harayama, K. (2011). 消費者の戦後史:闇市から主婦の時代へ (Shoubisha-no-senngoushi:Yamishi-kara-shubu-nojidai-e) [History of consumers post-WWII: Black markets to the era of housewives]. 日本経済評論社 (Nibon-keizai-hyoronsha).

Harris, E. (2009). Neoliberal subjectivities or a politics of the possible? Reading for difference in alternative food networks. Area, 41(1), 55-63. https://doi.org/10.1111/j.1475-4762.2008.00848.x

Hatano, T. (2008). The organic agriculture movement (teiker) and factors leading to its decline in Japan. Nougyou Shokuryo Keizai Kenkyu/Journal of Rural and Food Economics, 54(2), 21-34. (In Japanese). https://raikosgeorge.files.wordpress.com/2015/08/teikei-community-organic-agriculture.pdf

Hatano, T. (1998). 有機農産物流通の多様化段階における産消提携の新展開 [The diversification and its factors of the co-partnerships between organic producers and consumers affiliation on the organic agricutural movement in Hyogo Prefecture]. Journal of Rural Problem, 30(1), 1-10. https://www.jstage.jst.go.jp/article/arfe1965/30/1/3011/pdf

Healy, S., Ozselcuk, C., \& Madra, Y. M. (2020). Framing essay: Subjectivity in a diverse economy. In J. K. GibsonGraham \& K. Dombroski (Eds.), The handbook of diverse economies (pp. 389-401). Edward Elgar Publishing. https://www.elgaronline.com/view/edcoll/9781788119955/9781788119955.00056.xml 
Herrmann, G. M. (1997). Gift or commodity: What changes hands in the U.S. garage sale? American Ethnologist, 24(4), 910-930. https://doi.org/10.1525/ae.1997.24.4.910

Hisano, S., Akitsu, M., \& McGreevy, S. R. (2018). Revitalising rurality under the neoliberal transformation of agriculture: Experiences of re-agrarianisation in Japan. Journal of Rural Studies, 61, 290-301. https://doi.org/10.1016/i.jrurstud.2018.01.013

Honjoh, N. (2004). Japan's Organic Agriculture. Noubunkyo. (In Japanese).

Jentzsch, H. (2017). Abandoned land, corporate farming, and farmland banks: A local perspective on the process of deregulating and redistributing farmland in Japan. Contemporary Japan, 29(1), 31-46. https://doi.org/10.1080/18692729.2017.1256977

JOAA. (1994). JOAA History. Retrieved November 5, 2020, from https://www.1971joaa.org/ $\% \mathrm{E} 6 \% 9 \mathrm{C} \% \mathrm{AC} \% \mathrm{E} 4 \% \mathrm{BC} \% 9 \mathrm{~A} \% \mathrm{E} 3 \% 81 \% \mathrm{AB} \% \mathrm{E} 3 \% 81 \% \mathrm{~A} 4 \% \mathrm{E} 3 \% 81 \% 84 \% \mathrm{E} 3 \% 81 \%$ A6/about-us/about-us-html/\#teikeisystem

Kondoh, K. (2015). The alternative food movement in Japan: Challenges, limits, and resilience of the teikei system. Agriculture and Human Values, 32(1), 143-153. https://doi.org/10.1007/s10460-014-9539-x

Koretskaya, O., \& Feola, G. (2020). A framework for recognizing diversity beyond capitalism in agri-food systems. Journal of Rural Studies, 80, 302-313. https://doi.org/10.1016/j.jrurstud.2020.10.002

Krauss, E. S. (1988). The 1960s' Japanese student movement in retrospect. In G. L. Bernstein \& H. Fukui (Eds.), Japan and the World (pp. 95-115). Palgrave Macmillan UK. https://doi.org/10.1007/978-1-349-08682-5 6

McGreevy, S. R. (2012). Lost in translation: Incomer organic farmers, local knowledge, and the revitalization of upland Japanese hamlets. Agriculture and Human V alues, 29(3), 393-412. https://doi.org/10.1007/s10460-011-9347-5

McGreevy, S. R., \& Akitsu, M. (2016). Steering sustainable food consumption in Japan: Trust, relationships, and the ties that bind. In Sustainable Consumption (pp. 101-117). Springer. https://doi.org/10.1007/978-3-319-29665-4 7

McGreevy, S. R., Kobayashi, M., \& Tanaka, K. (2019). Agrarian pathways for the next generation of Japanese farmers. Canadian Journal of Development Studies/Revue Canadienne d'études Du Développement, 40(2), 272-290. https://doi.org/10.1080/02255189.2018.1517642

Myers, J. S., \& Sbicca, J. (2015). Bridging good food and good jobs: From secession to confrontation within alternative food movement politics. Geoforum, 61, 17-26. https://doi.org/10.1016/j.geoforum.2015.02.003

Nishiyama, M., \& Hirata Kimura, A. (2005). Alternative agro-food movement in contemporary Japan. The Technical Bulletin of the Faculty of Horticulture, Chiba University, 59, 85-96. https://agris.fao.org/agris-search/search.do?recordID=JP2006006929

Orito, E. (2014). 「提携」における“もろとも”の関係性に埋め込まれた「農的合理性」一霜里農場の「お 礼制」を事例として [Teikei as a “morotomo” relationship embedded in agrarian rationality: The experience of the "Orei-sei” system at Shimosato Farm]. Journal of Environmental Sociology, 20, 133-148. https://doi.org/10.24779/jpkankyo.20.0 133

Pickerill, J., \& Chatterton, P. (2006). Notes towards autonomous geographies: Creation, resistance and self-management as survival tactics. Progress in Human Geography, 30(6), 730-746. https://doi.org/10.1177/0309132506071516

Pretty, J., Sutherland, W. J., Ashby, J., Auburn, J., Baulcombe, D., Bell, M., Bentley, J., Bickersteth, S., Brown, K., Burke, J., Campbell, H., Chen, K., Crowley, E., Crute, I., Dobbelaere, D., Edwards-Jones, G., Funes-Monzote, F., Godfray, H. C. J., Griffon, M., ... Pilgrim, S. (2010). The top 100 questions of importance to the future of global agriculture. International Journal of Agricultural Sustainability, 8(4), 219-236. https://doi.org/10.3763/ijas.2010.0534

Renting, H., Marsden, T. K., \& Banks, J. (2003). Understanding alternative food networks: Exploring the role of short food supply chains in rural development. Environment and Planning A: Economy and Space, 35(3), 393-411. https://doi.org/10.1068/a3510

Rigg, J., Salamanca, A., \& Thompson, E. C. (2016). The puzzle of East and Southeast Asia's persistent smallholder. Journal of Rural Studies, 43, 118-133. https://doi.org/10.1016/j.jrurstud.2015.11.003

Rosenberger, N. (2017). Young organic farmers in Japan: Betting on lifestyle, locality, and livelihood. Contemporary Japan, 29(1), 14-30. https://doi.org/10.1080/18692729.2017.1256974 
Rosol, M. (2020). On the significance of alternative economic practices: Reconceptualizing alterity in alternative food networks. Economic Geography, 96(1), 52-76. https://doi.org/10.1080/00130095.2019.1701430

Samers, M. (2005). The Myopia of "Diverse Economies," or a Critique of the "Informal Economy." Antipode, 37(5), 875-886. https://doi.org/10.1111/j.0066-4812.2005.00537.x

Sarmiento, E. R. (2017). Synergies in alternative food network research: Embodiment, diverse economies, and morethan-human food geographies. Agriculture and Human Values, 34(2), 485-497. https://doi.org/10.1007/s10460-0169753-9

Smith, J., \& Jehlička, P. (2013). Quiet sustainability: Fertile lessons from Europe's productive gardeners. Journal of Rural Studies, 32, 148-157. https://doi.org/10.1016/j.jrurstud.2013.05.002

Suryanata, K., Mostafanezhad, M., \& Milne, N. (2020). Becoming a new farmer: Agrarianism and the contradictions of diverse economies. Rural Sociology, 86(1), 139-164. https://doi.org/10.1111/ruso.12355

Tregear, A. (2011). Progressing knowledge in alternative and local food networks: Critical reflections and a research agenda. Journal of Rural Studies, 27(4), 419-430. https://doi.org/10.1016/j.jrurstud.2011.06.003

Watts, D. C. H., Ilbery, B., \& Maye, D. (2005). Making reconnections in agro-food geography: Alternative systems of food provision. Progress in Human Geography, 29(1), 22-40. https://doi.org/10.1191/0309132505ph526oa

Wilson, A. D. (2012). Beyond alternative: Exploring the potential for autonomous food spaces. Antipode, 45(3), $719-737$. https://doi.org/10.1111/j.1467-8330.2012.01020.x

White, T. (2020). Direct producer-consumer transactions: community supported agriculture and its offshoots. In J. K. Gibson-Graham \& K. Dombroski (Eds.), The handbook of diverse economies (pp. 214-222). https://doi.org/10.4337/9781788119962.00033

Yagi, K. (2013). A study on the potential of organic agriculture in the Iga area. Taisei Gakuin University Bulletin, 15, 101 107. https://doi.org/10.20689/taiseikiyou.15.0 101

Yamamoto, N. (2020).「選べない食実践」の再評価：使い捨て時代を考える会/安全農産供給センターの野菜セット を事例に 山本奈美 [Teikei movement revisited: Non-customizable vegetable box as an alternative food practice]. Japanese Journal of Organic Agriculture Science, 12(2), 2-15. https://doi.org/10.24757/joas.12.2 2 